\title{
ろうのぬれの基礎的考察*
}

一好性に関する研究一（第 1 㫰）

和田次康**福 本

保***

\section{A Consideration on the Wetting with Brazing Alloys*}

-Studies on the Wettability (I) -

by Tsuguyasu Wada** and Tamotsu Fukumoto***

\begin{abstract}
An equation has been derived for wetting equilibrium between molten alloy and solid metallic surface by taking account of terms for the potential energy of gravity and for alloying in the vicinity of interface. The equilibrium condition is given by

$$
\sigma_{S}=\sigma_{L} \cos \theta+\left(\sigma_{t . S}+f_{a}\right)-\varepsilon
$$

where $\sigma_{S}, \sigma_{L}$ and $\sigma_{L S}$ are respectively the surface energies of the solid and the liquid phases and the interfacial energy between them, $\theta$ is the contact angle, $f_{a}$ the alloying energy per unit interface, and $\varepsilon$ the energy due to gravity. It was pointed out that $f_{a}$ could have a large value compared with the interfacial energy. The value of $f_{a}$ was estimated for molten silver containing palladium in contact with a nickel plate, and the result was compared with experimental facts.
\end{abstract}

\section{1. 緒言}

金属のろう付では，溶融したろうは母忉のせまいすき まに浸入しなければならない、したがってろうが母材を

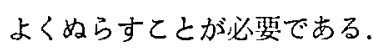

金属表酒のろうのぬれを理解するのに，じ伸うらい大 きくわけて 2 つの考え方があったようである. その $1 つ$ は母材，万う忉の表而エネルギ一，母材/万う材の界面 エネルギーの大小関係がぬれの良否をきめるとする考え 方である，溶融したろう材の表面張力の測定”およびそ れにあとずくぬれ性の检討2)はこの立場にたつものであ ろう。他の1つは母材/万う材の界百にちける合金生成 や溶解度を重視し，相互の合金生成倾向や固溶度の大き いものは好がよいとする若え万゙である。

てれらはいずれも一面の正しさを全んではいるが，な お検討を㼭する点があると思われる，たとえば，实際の ろうは多少と屯母材と合金をつくる成分を念んでいる が，その場合表面エネルギー理諭ではどう取报ったらよ いか.このようなときは母材とろう材の界面エネルギー は林質的にかなりあいまいなものよなるのはさけられな い. また合金層生成に注目することはたしかに年性的に はぬれの判定方法として有用であり，実際上は役立つこ

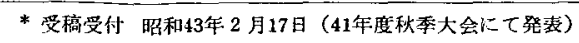

** 正. 員金属材料技術研焭所 Member, National Research Institute for Metals

**** 金属材料技術研究所 National Research Institute for Metals
とが多いけれども，ぬれの定量的な表見はどうすればよ いか，といったてとが問频として残る.

この報告は，それらに対する1つの解決法を見い沮そ うとするあのである。方釙としては如平衡式のなか に合金化のエネルギーを扣えるとと，さらにその合金化 のエネルギーの大きさを推算し、实験事実と比較するこ とである。また，ぬれの平衡式のなかにはじゆうらい䨘 力のポテンシャルエネルギーの项は蓨峈されていたが, その項についても検討を扣えた。

ろうのぬ礼対して，母材との界面における現象が大 きな影響力をもつととはすでに Blanc4)らむ指摘してい るが，定量的な議論はまだ見当たらない。最近 Wassink $^{5)}$ は固相金属表面倿対する溶融金属のぬれについて 眮味ある議䑳を発表した，その報告では，母材扰よび溶 融金属がそれぞれ純金属であるような系に対してはすぐ れた取りあつかいを行なっている．ただ第 3 成分が扣わ った場合については，さらに補足する必要があろう。

一般に，1つの金属の融点附近での液相/固相間の界 面エネルギーは，乙の金属の融解熱にほぼ比例する6). 融解熱は融点にほぼ比例するから, 純金属の液相/固相 界面エネルギーは，どの金属でもほば等しいエントロピ 一項をむっていると考えてよいだろう。このととは純金 属の界面エネルギーは界面における構造の乱れに起因す るとして理解される.し加し，合金の波相/固相界面の エネルギーは：構造の乱ればかりでなく，溶質成分の分 


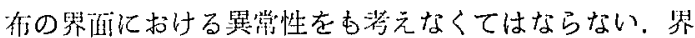
面における溶頃分布之それによるエネルギーの理諭的取 りあつかいは Hillert ${ }^{7}, \mathrm{Cahn}^{8}$, Meijering ${ }^{93}$ らによって

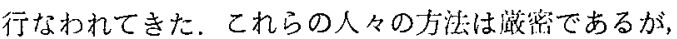
正則溶液的なモデルであるから金属成分間の合金に対し てもっ之むよくあてはまるであるう。また表面における 溶質成分の灌化に対して Gibbs または Langmuir の吸 着等温式を㐫用することは以前加ら行なわれているが， 最近 Gjostein ら ${ }^{109}$ は $\mathrm{Fe} . \mathrm{C}$ 合金の $\alpha-\gamma$ 相界面エネル ギー化芯用して叔り，またKaufman ${ }^{11)} 2 ， 3$ の波体 合金の表面エネルギーの競明に応用している。

いずれにしてす，合金に招ける界面エネルギーは組成 的な项が大きいという性格があるといえよう。て意味 では合金化エネルギーに本質的には近いのであるが，乙 の羭文ではこれとはまた別な意味で合金化エネルギーを 考えることにする。

すなわち, 溶融したろうのうち，母材と溶解し合う成 分は母材侧住撒すると考元られる，亏の埸合のエネル ギー変化は，目忉にその成分が溶解したときの程分混合 エネルギーにより与えられる。とのエネルギーは，あと で示すように，界面エネルギーにくらべてかなり大きな あのとなる可能性がある。したがって，じゅうらいのぬ れの承衡式に対し，界面エネルギーととあにとの合金化 エネルギーを加えて考えるというのが，乙の論文の趣旨 である。

\section{2.ぬれの平衡式}

Fig. 1 のような液滴のモデルを考えよう，母材，万う 材の表面エネルギーをそれぞれ $\sigma_{S}, \sigma_{J}$ ，母材/万う材の 界面エネルギーを $\sigma_{S I}$ とすれば，じゅうらい多くの文 献に示されているぬれの平衡式は

$$
\sigma_{S}=\sigma_{L S}+\sigma_{L} \cos \theta
$$

ここで $\theta$ は平衡接触角である。

ての式は合金化エネルギーおよび重力によるポテンシ ヤルエネルギーが無視できる埼合に成り立つ。乙れらが 無視できない場合も，同様にろうの液游を会む系全体の エネルギーが見かけ上極小になる点で平衡になるとし て, ぬれの平衡式が求められる。

界面付近で合金層が生成する場合，それによる自由工 ネルギー变化を単位面皘当り $f_{a}$ とする，母忉表面，万

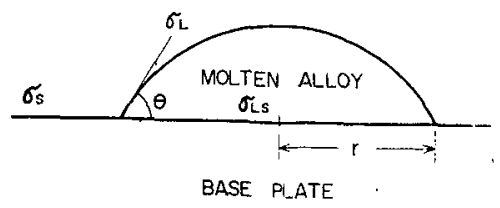

Fig. 1 Model of molten alloy on the base plate

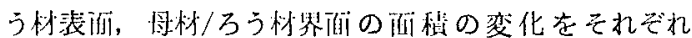
$d S_{S}, d S_{L,} d S_{L S}$ 亡すれば，平衡条件仗

$$
\sigma_{S} d S_{S}+\sigma_{J} d S_{I}+\left(\sigma_{L, S}+f_{a}\right) d S_{L S}+d P_{g}=0 \cdots(2)
$$

ここで $d P_{g}$ は系の重力に上るポテンシャルエネルギ 一の変化である。

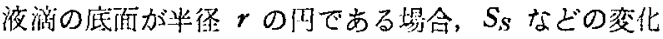
が $r$ のによるとすれば

$$
\sigma_{S} \frac{d S_{S}}{d r}+\sigma_{L} \frac{d S_{L}}{d r}+\left(\sigma_{L S}+f_{a}\right) \frac{d S_{L S}}{d r}+\frac{d P_{g}}{d r}=0
$$

一般的には（2）または（3）をとくことによりぬれの 平衡式が求められる，以下に（3）式の各项について检 討しょう。

(2.1) $d S_{S} / d r$ および $d S_{L S} / d r$

ろう材による母材の浸䬶が無視できるときは

$$
-d S_{S} / d r=d S_{L S} / d r=2 \pi r
$$

(2.2) $d S_{I} / d r$

$d S_{L} / d r$ は一般に複雑な值をとる，乙こでは簡単のた めに液游か球面の一部之考元上う。年の場合, 波游の容 䟣を $V$ とすれば

$$
V=\frac{1}{3} \pi r^{3} \cdot \frac{\sin \theta(2+\cos \theta)}{(1+\cos \theta)^{2}}
$$

$V=$ const·として微分し，さらにつぎの 2 つの関係（6）, （7）を代入す机ば（8）式がえられる。（付録参照）

$$
\begin{aligned}
& \left(\begin{array}{l}
d \theta \\
d r
\end{array}\right)_{V}=-\frac{\sin \theta(2+\cos \theta)}{r} \\
& S_{L}=2 \pi r^{2} /(1+\cos \theta) \\
& \left(\frac{d S_{I}}{d r}\right)_{V}=\frac{4 \pi r}{1+\cos \theta}+\frac{2 \pi r^{2} \sin \theta}{(1+\cos \theta)^{2}}\left(\frac{d \theta}{d r}\right)_{V} \\
& \quad=2 \pi r \cos \theta
\end{aligned}
$$

(2.3) $d P_{g} / d r$

$d P_{g} / d r$ は球面モデルによりつぎのように与えられる。 (付録参照)

$$
\begin{aligned}
& d P_{g} / d r=-\frac{\rho g \pi r^{3}}{3} \cdot \frac{(1-\cos \theta)}{(1+\cos \theta)} \\
& \quad \equiv-2 \pi r \cdot \varepsilon
\end{aligned}
$$

ただし

$$
\varepsilon=\frac{\rho g r^{2}}{6} \cdot \frac{(1-\cos \theta)}{(1+\cos \theta)}
$$

(4)，(8)掠よび（9）を（3）に代入して

$$
-\sigma_{S}+\sigma_{L} \cos \theta+\sigma_{L S}+f_{a}-\varepsilon=0
$$

これは (1) 式の $\sigma_{L S S}$ を $\left(\sigma_{t, S}+f_{a}-\varepsilon\right)$ でおきかえたす のに等しい.

$\varepsilon$ の傎はたとえば $\rho=7, r=0.5 \mathrm{~cm}, \cos \theta=0.7$ とすれ ば約 $50 \mathrm{erg} / \mathrm{cm}^{2}$ となり，無視できない大きさとなる。 $r$ が小さいとき，または $\theta$ の小さいときは $\varepsilon$ は小さく

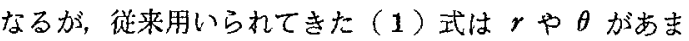
り大きくない笵围で成古する近似式であることに留意す 


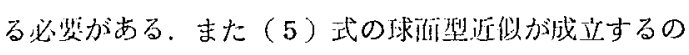
は

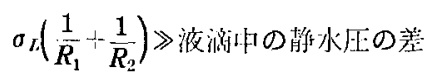

の場合である。ここで $R_{1}, R_{2}$ は 1 つの転に対する 2 方 向の液㵝面の临半烽である， $R_{1} \simeq R_{2}$ とみなすならば, 球面近似が成り立つのは

$$
\frac{2 \sigma_{I}}{R} \gg \rho g R(1-\cos \theta)
$$

すなわち

$$
\frac{2 \sigma_{r}}{\rho g} \gg \frac{r^{2}}{1+\cos \theta}
$$

の埸合である，ろうの比重は10程度であり， $\sigma_{L}$ は 1000 $\mathrm{erg} / \mathrm{cm}^{2}$ 程度であるから

$$
r^{2} \ll \frac{1+\cos \theta}{5}
$$

ならばよい球面近似が成り吉つ。

\section{3 . 界面付近の溶質分布について}

$f_{a}$ について議淪を淮める㓩に，母材/ろう材の界面で 合金成分がごのように分布するかを簡觜に考察する。

Fig. 2 には考えられるいくつかのケースについて，合金 成分分布の浱度䉼面を示す，a1，a2 はいずれも注目する 合金成分が母材と単純な固溶体を作る埸合で，その成分 と，ろう材ならびに母材の主成分上の親利力の大小によ

$(a)$
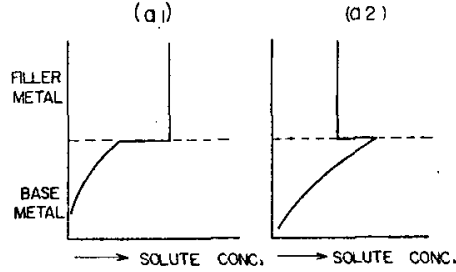

(bl)
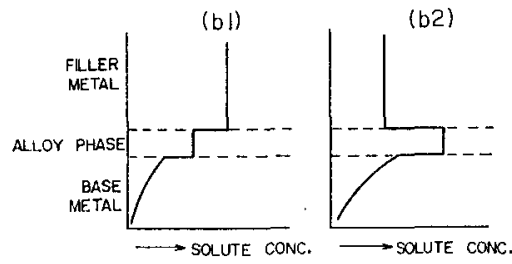

(CI)
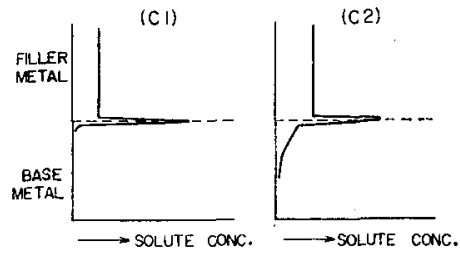

Fig. 2 Various types of distribution of solute. a: Simple-diffusion type,

b: Alloy-phase-formation type, c; Interface-segregation type.
Table 1 Typical combinations of filler metal/base metal corresponding to the classification in Fig. 2

\begin{tabular}{c|c|c|c}
\hline $\begin{array}{c}\text { Classification } \\
\text { in Fig. 2 }\end{array}$ & Filter Metal & $\begin{array}{c}\text { Relevant } \\
\text { Alloying Element }\end{array}$ & $\begin{array}{c}\text { Base } \\
\text { Metal }\end{array}$ \\
\hline a 1 & $\mathrm{Ag}+\mathrm{Cu}$ & $\mathrm{Cu}$ & $\mathrm{Fe}$ \\
$\mathrm{a} 2$ & $\mathrm{Ag}+\mathrm{Cu}+\mathrm{Ni}$ & $\mathrm{Ni}$ & $\mathrm{Fe}$ \\
\hline $\mathrm{bl}$ & $\mathrm{Zn}$ & $\mathrm{Zn}$ & $\mathrm{Cu}$ \\
$\mathrm{b}^{2}$ & $\mathrm{Cu}+\mathrm{Si}$ & $\mathrm{Si}$ & $\mathrm{Fe}$ \\
$\prime \prime$ & $\mathrm{Ag}+\mathrm{Cu}$ & $\mathrm{Cu}$ & $\mathrm{Ti}$ \\
\hline $\mathrm{cl}$ & $\mathrm{Ag}+\mathrm{Li}$ & $\mathrm{Li}$ & $\mathrm{Fe}$ \\
$\mathrm{c} 2$ & $\mathrm{Cu}+\mathrm{P}$ & $\mathrm{P}$ & $\mathrm{Cu}$ \\
\hline
\end{tabular}

り，a1 のように母忉側の洋衡湡度がろう材よりあ低く なる場合上，a2 のように逆に高くなる場合とがあるで あろう。b1，b2 は界面に新しい合金相が生ずる罚合であ る。合金相は鉝属間化合物のように組成の门のない煬合 とやのある埸合が考えられ，图には巾のない煌合を示し たが，乙の尿内で湍度勾配をもつ䍜合もあるであろう。 その場合の港度勾配の大小，したがって合全相の厚さは 各相における搪政主数の大小と関係するであろう。

また c1，c2 はとくに界而で濰化すると考えられる例 である、この塌合は $f_{a}$ よりもむしろ $\sigma_{I S}$ に影響する と考えられる。一般に非金属元溸はこの傾向怔強いが，

$\mathrm{P}$ や Li は界面エネルギ一を下げることが知られてお り，ての夕イプに属するとみられる。とのうち $\mathrm{P}$ は $\mathrm{Li}$ より手材への溶解度が大きいので，母材側にやや应潵 することになる，a，b の夕イプと c のタイプとが霍な りあって起こるととも考えられる。

これら 6 つの種類に属するとみられる代表的なるう忉 /材の組合せを Table 1 に亦す。

\section{4. $f_{a}$ について}

$f_{a}$ は単位面勫当りの積分混合エネルギーであるから，

$$
f_{a}=\int_{0}^{\infty} \frac{\Delta F^{\mu}(\mathbf{x}, \mathbf{t})}{V_{m}} d X
$$

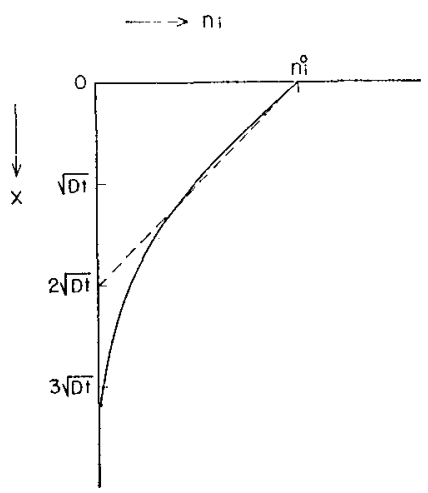

Fig. 3 Distribution of solute in the diffusion layer, 
ここで $X$ は母忉表酒加ら内部方何への距離（Fig. 3 参 照)， $\Delta F^{M}$ は万う材成分之母忉の 1 モル当りの積分湿合 エネルギー， $V_{m}$ は合金 1 モル当りの体穔である.

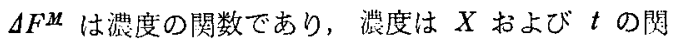
数である。乙れを計算に上り求める前に， $f_{a}$ の大体の 大きさについて触れておきたい，固相の鉄中の置换烈元 素の拡散定数は $1000^{\circ} \mathrm{K}$ 付近で $10^{-11} \mathrm{~cm}^{2} / \mathrm{sec}$ 程度であ る，ろう付時間を10秒とすれば昖散の特性距離 $\sqrt{ } \bar{D} t$ は $10^{-5} \mathrm{~cm}$ となる．乙の距離内の平均の $\Delta F^{M}$ を 1 原子当 り $k T$ 程度, $V_{m}$ を $10 \mathrm{~cm}^{3} / \mathrm{mol}$ とすれば

$$
\begin{aligned}
f_{a}=10^{-6} \mathrm{NkT} & \simeq 2 \times 10^{-3} \mathrm{cal} / \mathrm{cm}^{2} \\
& \simeq 8 \times 10^{4} \mathrm{erg} / \mathrm{cm}^{2}
\end{aligned}
$$

界而エネルギーは $10^{3} \mathrm{erg} / \mathrm{cm}^{2}$ のオーダーであるから， この $f_{a}$ の值はかなり大きいあのであることがわかる. あちろんてれは $\Delta F^{\mu}$ の值によるので，さらに以下に詳 練に检討する。

$\Delta F^{M}$ は万う材中の节る成分が母材中に移行する反応 に対応しているから，その点考虚して幖準状態を決め る必要が西る。

簡単のために，万う材は基本成分と合金成分 $i$ ，母材 は基本成分 $A$ 加らなるしよう，そのとき， $\Delta F^{M}$ は次 のように書くことができる。

$$
\Delta F^{M}=n_{i}\left(F_{i}-\bar{F}_{i}^{0}\right)+\left(1-n_{i}\right)\left(F_{A}-F_{A}{ }^{0}\right) \cdots
$$

ここで $F_{i} ， F_{A}$ は尺れぞれ $i$ のモル分率が $n_{i}$ である $A-i$ 合金中の $i$ および $A$ の部分モルエネルギー, $\quad F_{i}{ }^{0}$ および $F_{A i}$ はそれぞれ標準状態における $i$ および $A$ の部分モルエネルギーである． $A-i$ 合金が正則溶液と みなすととができるならば（付録参照）

$$
\begin{aligned}
& \Delta F^{M}=R T\left[n_{i} \ln n_{i}+\left(1-n_{i}\right) \ln \left(1-n_{i}\right)\right] \\
& \quad+n_{i}\left(1-n_{i}\right) w-n_{i}\left[R T \ln n_{i}{ }^{0}+\left(1-n_{i}\right)^{2} w\right]
\end{aligned}
$$

ことで $n_{i}$ はろう材中の成分のモル分率， $n_{i}{ }^{0}$ は母忉界 面に求けるモル分率，wは interchange energy であ る. $i$ の標準状態は万う忉中の $i$ 成分（すなわち母忉界 面の状態)，A の標準状態は純物質上する．合金の熱力 学的性質として従来実測されているの混合熱, 混合の 過剩自由エネルギー，各成分の活量などであるから こ れからつぎの関係により $w$ を概算するととができる。

(付録参照)

$w \simeq 4 \times$ (最大混合熱) (excess entropy $=0$ の場合)

$w \simeq 4 \times$ (最大過剩湿合エネルギー)

$w=\frac{R T \ln r_{i}}{\left(1-n_{i}\right)^{2}}(r: i$ のラウール活暈係数 $)$

$n_{i}$ は $X, t$ に対してつぎのようにあらわされる.

$$
n_{i}=n_{i}[1-\operatorname{erf}(X / 2 \sqrt{D t})]
$$

（17）式を微分すれば

$$
d X=-\frac{\sqrt{ } \pi \sqrt{ } D t}{n_{i}{ }^{0}} \exp \left(\frac{X^{2}}{4 D t}\right) d n_{i}
$$

したがって（14）式は

$$
f_{a}=\frac{\sqrt{\pi} \sqrt{D t}}{n_{i}{ }^{0} V_{m}} \cdot \int_{0}^{n_{i}{ }^{0}} \Delta F^{M} \exp \left(\frac{X^{2}}{4 \bar{D} t}\right) d n_{i} \cdots \cdots(19)
$$

（19）式は単純拡散型すなわち Fig. 2 の a1, a2 型の 系について求めたものである，合金相生成型の屯のにつ いても原理的には同様な取りあつかいができよう。合金 相生成型の $\hat{f}_{a}$ は

$$
f_{a}=\int_{0}^{X_{1}} \frac{\Delta F_{1}^{M}(X, t)}{V_{m 1}} d X+\int_{X_{1}}^{\infty} \frac{\Delta F_{2}{ }^{M}(X, t)}{V_{m 2}} d X
$$

ここで $X_{1}$ は合金相の暻さよする．Fig. 2 に示すように 合金相の組成がほぼ一定の場合は， $F_{i}$ はこの相内でほ ぼ一䇥とみてよいであろう。その場合，その合金相の生 成エネルギーを $\Delta F_{1} M$ （標準状態は上記の通りとする） とすれば

$$
\begin{aligned}
f_{a} & =X_{1} \Delta F_{1}^{M} \\
& +\frac{\sqrt{\pi} \sqrt{D t} t}{n_{i}{ }^{0} V_{m}} \int_{0}^{n_{i}{ }^{0}} \Delta F_{2}^{M I} \exp \left(\frac{\left(X-X_{1}\right)^{2}}{4 D t}\right) d n_{i}
\end{aligned}
$$

ただし $X_{1}$ は時間の関数であるから， $f_{a}$ を計算するに は適当な方法で $X_{1}$ を推定することが必要となろう。

以下实際の例について計算を行なう。

\section{Ni に対する銀ろうのぬれ について}

Adamec と Rhoda ${ }^{12)}$ は $\mathrm{Ni}$ および Ni 合金に対する 銀万うのぬれにおよばす Pd および Pt 湑加の效果を測 定した。 $\mathrm{Ag}$ は $\mathrm{Ni}$ にほとんど固溶しないが，Pd ある いは Pt は Ni と全率固溶体をつくる。したがって Pd および Ptを母材に溶解吉る成分とみなして上記の方法 を応用することができる。

$\mathrm{Ni}$ と $\mathrm{Pt}, \mathrm{Pd}$ との合金の熱力学的性貿については Schwerdtfeger と Muan ${ }^{13\rangle}$ が雪測している.その綃果 の 1 部， $1,200^{\circ} \mathrm{C}$ における $\mathrm{Pt}$ および $\mathrm{Pd}$ の活聂を Table 2 に示す。 との結昭はまた独立に Ni-Pd につい て測定した Bidwell とSpeiser $\left.{ }^{14}\right)$ の結果ともほぼ一致

Table 2 Activity components of Ni-Pd and Ni-Pt systems at $1200^{\circ} \mathrm{C}^{(3)}$

\begin{tabular}{l|l|lllll}
\hline \hline \multirow{2}{*}{$\mathrm{Ni} \sim \mathrm{Pd}$} & $\begin{array}{c}\text { Mole fraction } \\
\text { Pd or Pt }\end{array}$ & 0.1 & 0.2 & 0.3 & 0.4 & 0.5 \\
\hline \multirow{2}{*}{$\mathrm{Ni}-\mathrm{Pt}$} & $a_{\mathrm{Ni}}$ & 0.91 & 0.83 & 0.74 & 0.62 & 0.49 \\
& $a_{\mathrm{Pd}}$ & 0.09 & 0.14 & 0.21 & 0.30 & 0.39 \\
\hline & $a_{\mathrm{Ni}}$ & 0.88 & 0.74 & 0.57 & 0.40 & 0.26 \\
& $a_{\mathrm{Pt}}$ & 0.02 & 0.04 & 0.09 & 0.18 & 0.30 \\
\hline
\end{tabular}


する.

てれらの結果のうち, Ni-Pd 系は正則溶液からいくぶ んはずれているが，理想溶液からのずれはごく小さい. したがって Ni-Pd 系に対しては $w$ の項は一応無視し てもよいであろう。いっぽう Ni-Pt 系では理想溶液か らのずれはやや大きく，正則溶液に近い挙動を示す。 $w_{\mathrm{Ni}-\mathrm{Pt}}$ はほぼ $7 \mathrm{kcal} / \mathrm{mol}$ である.したがって，以下 ではまず $w=0$ とした場合の（19）式の皘分結果と，そ れに対する $w$ の項の補正とを考えたい.

理想溶波の系については

$$
\begin{aligned}
& \Delta F^{M}=R T\left[n_{i} \ln n_{i}+\left(1-n_{i}\right) \ln \left(1-n_{i}\right)\right. \\
& \left.-n_{i} \ln n_{i}{ }^{0}\right]
\end{aligned}
$$

$X^{2} / 4 D t$ の值は (17) 式より $n_{i} / n_{i}{ }^{0}$ の值が決まれば決ま るので, パラメータの数は 1 つとなる. Fig. 4 に積分值

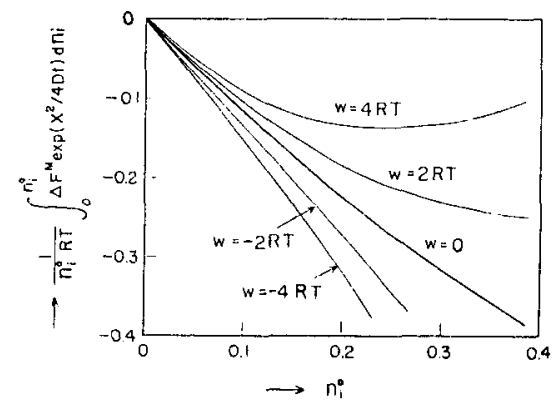

Fig. 4 Value of $\frac{1}{n_{i}^{\circ} R T} \int_{0}^{n_{i} 0} \Delta F \mathrm{M} \exp \left(X^{2} / 4 D i\right) d n_{i}$

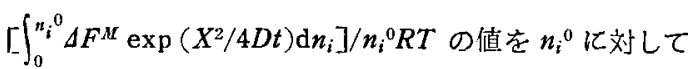
図示した，積分は図上積分によったものである，ての図 は理覀溶液に対するもの之， $w$ を $-4 R T$ ないし $4 R T$ の範囲で変化させた場合とを示す，乙の程度の $w$ 值 では，合金成分が稀薄な場合は $f_{a}$ にあまり大きな影響 はない。

(19）式で $f_{a}$ を計算するのであるが，ここで $D$ は $\mathrm{Ni}$ の自己昖散係数を用い， $D=1.6 \times 10^{-10} \mathrm{~cm}^{2} / \mathrm{sec}^{15)}, t$ は

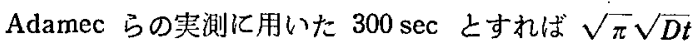
$=3.88 \times 10^{-4} \mathrm{~cm}, V_{m}=7 \mathrm{~cm}^{3}$ とすれば $\sqrt{\pi} \sqrt{D t} / V_{m}=$ $5.6 \times 10^{-5} \mathrm{~cm}^{-2}$ となる。乙れらの值を用いて計算した

Table 3 Calculated value of $f a$ for Ni-Pd, Pt

\begin{tabular}{|c|c|c|c|}
\hline$n_{i} 0$ & $\underbrace{\int_{0}^{n_{i} 0} J F M \exp \left(X^{2 / 4 D t}\right) d n_{i}}_{0}$ & \multicolumn{2}{|c|}{$f_{a}, \mathrm{cal} / \mathrm{cm}^{2}$} \\
\hline $\mathrm{Pd} ; 0.05$ & -0.05 & \multicolumn{2}{|c|}{$-0.82 \times 10^{-2}$} \\
\hline 0.10 & -0.12 & -2.0 & $"$ \\
\hline 0.15 & -0.17 & -2.8 & $"$ \\
\hline Pt: 0.05 & -0.04 & -0.65 & $"$ \\
\hline 0.10 & -0.10 & -1.6 & $"$ \\
\hline 0.15 & -0.14 & -2.3 & $"$ \\
\hline
\end{tabular}
systems at $1200^{\circ} \mathrm{C}$ $f_{a}$ の値を Table 3 に示す.

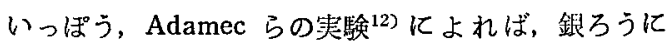
Pd または Pt を添加するとき, 約 10 at \%程度の添加 に上り接触角は 0 となる。 (Fig. 5 参照). $1200^{\circ} \mathrm{C}$ に戈 いて $\sigma_{\mathrm{Ag}}$ は約 $900 \mathrm{erg} / \mathrm{cm}^{2}, \sigma_{\mathrm{Ni}}$ は約 $1980 \mathrm{erg} / \mathrm{cm}^{2}$, $\sigma_{\mathrm{Ag} / \mathrm{Ni}}$ は $\theta=30^{\circ}$ として約 $1300 \mathrm{erg} / \mathrm{cm}^{2}$ となる。完 全にぬれるためには

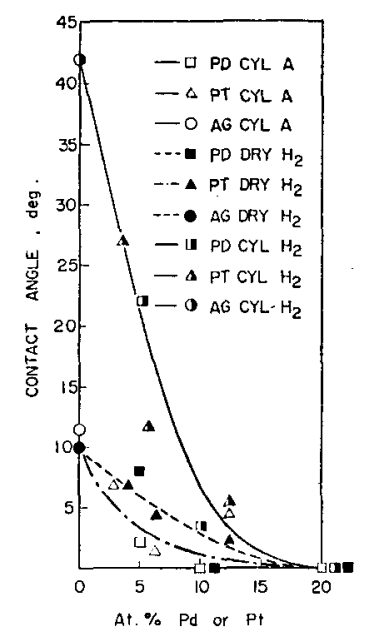

Fig. 5 Effect of platinum metals on the contact angle of silver on Inconel at $1200^{\circ} \mathrm{C} .{ }^{12}$ )

$$
\sigma_{\mathrm{Ag}}+\left(f_{a}+\sigma_{\mathrm{Ag} / \mathrm{Ni}}\right)<\sigma_{\mathrm{Ni}}
$$

なる条件が満足されなければならないから， $\sigma_{\mathrm{Ag}}, \sigma_{\mathrm{Ag} /}$ $\mathrm{Ni}$ が Pd の添加により変化しないとすれば， $f_{a}$ は約 $-200 \mathrm{erg} / \mathrm{cm}^{2}$ 以下であることを装する。乙れは単位を 変換すると約 $-4.8 \times 10^{-6} \mathrm{cal} / \mathrm{cm}^{2}$ となる．乙の値を Table 3 の $f_{a}$ 之比較する之，(23）式は明らか飞満足 されることがわかる。

ただ，実測される $f_{a}$ は，予想される $f_{a}$ よりあかな り大きいてとが注目される。乙れは $\sigma_{\mathrm{Ag} / \mathrm{Ni}} や \sigma_{\mathrm{Ag}}$ の 变化あるいは $n_{\mathrm{Pd}^{0}}$ の値など末知の因子が多いととも原 因であろうが実際の $\sqrt{ } \overline{D t}$ の值はこてで用いたよりああ つと短いことが最大の原团ではないかと考えられる。る うは中心からしだいに外周方问に拡がっていくのであ

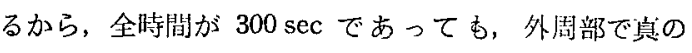
Driving force として効果があるのはきわめて短㭙間の $t$ 亿相当する拡散層之考えられる。乙の点については, 本方法による妨の評価林いては $f_{a}$ は時間ととあに 変化し, 真の意味での平衡ではない点に留意して, さら に詳細な検討が必要と思われる。

なおすう一つ指摘しておきたいのは, Adamec らの奏 験 ${ }^{12}$ はインコネルを母材として朽り，表面の酸化物層の 生成条件などが純 Ni よやや異なると考えられる点であ 
る.著者らはさらに純 $\mathrm{Ni}$ を材としたときの実験を行 ないつつあるが, $f_{a}$ の効果はその場合はさらに大きい ようである．乙れはまた別の機会に報告したい．

\section{6. 結語}

じゅうらいろうのぬれを説明するのに用いられていた 表面エネルギーおよび界面エネルギーの平衡関係に，界 面における合金化のエネルギーおよび重力のポテンシャ ルエネルギーの項を加えることを試みた。これは，今ま で経験的に母材之固溶体あるいは金属間化合物を作る成 分を含む万うは如がよいといわれていた事実を定冒的 飞表現する一方法と考えられる，合金化のエネルギーは 一般淸間の関数之侾えられるが，大きさとしてはかな り大きく，合金成分のわづかな量でもぬれに大きな影響

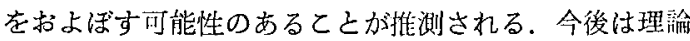
の精密化，雪験之の比較についてさらに検討を重权てゆ きたいと考えている， $f_{a}$ は今回は積分混合エネルギー として与えたが，おそらく正確には時間のファクターが 入った量であろうし，ろうの搪がりに対しては周刃部で のエボルギー関係が支配的となるのであるう，それらに ついてはさらに検討する予定である。

\section{参 考 文 献}

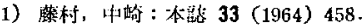

2) 藤村, 中崎：林脽 34 (1965) 696 。

3）石井, 体誌 34 (1965) 734.

4) G.M.A. Blanc, J. Colbus and C.G. Keel : Weld. J. 40 (1961) $210-s$

5) P.J. Klein Wassink : J. Inst. Metals, 95 (1967) 38.

6) J.H. Hollomon and D. Turnbull : Progress in Metal Physics. Vol. 4, (1953) 333

7) M. Hillert : Acta Met., 9 (1961) 525.

8) J.M. Cahn and J.E. Hilliard: J. Chem. Phys., 28. (1958) 258

9) J.L. Meijering: Acta Met., 14 (1966) 251.

10) N.A. Gjostein, H.A. Domian, H.I. Aaronson and E. Eichen: Acta Met., 14 (1966) 1637

11) S.M.Kaufman: Acta Met., 15 (1967) 1089.

12) J.B. Adamec and R.N. Rhoda: Weld. J. 40 (1961) 330-s.

13) K. Schwerdtfeger and A. Muan : Acta Met. 13 (1965) 509.

14) L.R. Bidwell and R. Speiser : Acta Met., 13 (1965) 61

15) R.H. Hoffman, F.W. Pikus and R.A. Ward: Trans. AIME 206 (1956) 483.

\section{〔付録〕}

(1) $\left(d S_{t} / d r\right)_{V}$ の眿出

ろうは球面の1部であると若えよう。(Fig. A-1 参

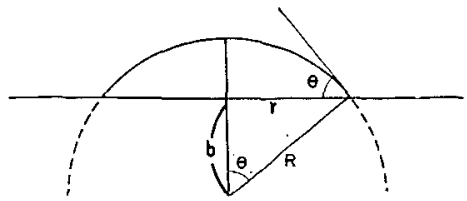

Fig. A-1 The spherical cap model of molten metal
照) そのときろうの体積 $V$, 表面皘 $S_{L}$ はそれぞれ

$$
\begin{aligned}
S_{L} & =\int_{b}^{R} 2 \pi R d x=2 \pi R(R-b)=2 \pi R^{2}(1-\cos \theta) \\
V & \left.=\int_{b}^{R} \pi\left(\sqrt{R^{2}-x^{2}}\right)^{2} d x=\mid \pi R^{2} x-\frac{x^{3}}{3}\right)\left.\right|_{b} ^{R} \\
& =\pi\left(\frac{2}{3} R^{3}-R^{2} b+\frac{b^{3}}{3}\right)=\frac{1}{3} \pi R^{3}(2-3 \cos \theta \\
& \left.+\cos ^{3} \theta\right)
\end{aligned}
$$

(A-2) 式に $R=r / \sin \theta$ を代入して

$$
V=\frac{1}{3} \pi r^{3} \cdot \frac{\sin \theta(2+\cos \theta)}{(1+\cos \theta)^{2}}
$$

これを $r$ で微尔すれば

$$
\begin{aligned}
\frac{d V}{d r} & =V\left[\frac{3}{r}+\left\{\frac{\cos \theta}{\sin \theta}-\frac{\sin \theta}{2+\cos \theta}+\frac{2 \sin \theta}{1+\cos \theta}\right\} \frac{d \theta}{d r}\right] \\
& =V\left[\frac{3}{r}+\frac{3}{\sin \theta(2+\cos \theta)} \cdot \frac{d \theta}{d r}\right] \cdots \cdots \cdots(\mathrm{A}
\end{aligned}
$$

$V$ がー一地の場合は左辺を 0 とおいて

$$
\left(\frac{d \theta}{d r}\right)_{V}=-\frac{\sin \theta(2+\cos \theta)}{r}
$$

(A-1) より

$$
S_{L}=2 \pi r^{2} \frac{1-\cos \theta}{\sin ^{2} \theta}=\frac{2 \pi r^{2}}{1+\cos \theta}
$$

これをとで微分すれば

$$
\left(\frac{d S_{L}}{d r}\right)_{V}=S_{L}\left[\frac{2}{r}+\frac{\sin \theta}{1+\cos \theta} \cdot\left(\frac{d \theta}{d r}\right)_{V}\right]=2 \pi r \cos \theta
$$

(2) $P_{g}$ の項について

$$
\begin{aligned}
P_{g} & \left.=\int_{b}^{R} \rho g \pi \sqrt{R^{2}-x^{2}}\right)^{2}(x-b) d x \\
& =\rho g \pi\left(\frac{1}{4} R^{4}-\frac{2}{3} R^{3} b+\frac{1}{2} R^{2} b^{2}-\frac{1}{12} b^{4}\right) \\
& =\frac{\rho g \pi R^{4}}{12}(1-\cos \theta)^{3}(3+\cos \theta) \cdots \cdots \cdots
\end{aligned}
$$

$R=r / \sin \theta$ を代入すれば

$$
P_{g}=\frac{\rho g \pi r^{4}}{12} \cdot \frac{(1-\cos \theta)(3+\cos \theta)}{(1+\cos \theta)^{2}} \cdots \cdots \cdots(\mathrm{A}-9)
$$

$r$ で微分すれば

$$
\begin{aligned}
& \left(\frac{d P_{g}}{d r}\right)_{V}=P_{g}\left[\frac{4}{r}+\left\{\frac{\sin \theta}{1-\cos \theta}-\frac{\sin \theta}{3+\cos \theta}\right.\right. \\
& \left.\left.\quad+\frac{2 \sin \theta}{1+\cos \theta}\right\}\left(\frac{d \theta}{d r}\right)_{V}\right]=-\frac{4 P_{\mathcal{g}}}{r} \cdot \frac{1+\cos \theta}{3+\cos \theta} \\
& =-\frac{\rho g \pi r^{3}}{3} \cdot \frac{1-\cos \theta}{1+\cos \theta} \equiv-2 \pi r \varepsilon \cdots \cdots \cdots(
\end{aligned}
$$

ただし

$$
\varepsilon=\frac{\rho g r^{2}}{6} \cdot \frac{1-\cos \theta}{1+\cos \theta}
$$

または（A-3）により を消去すれば

$$
\varepsilon=\frac{\rho g}{6}\left[\frac{3 V(1-\cos \theta)}{\pi(2+\cos \theta)}\right]^{2 / 3}
$$

(3) $\Delta F^{M}$ について

$N_{A}$ ケの $A$ 原子からなる綕晶と， $N_{i}$ ケの $i$ 原子之 
からなる結晶が混合し，完全に無秩序に配列した固溶体 をつくるとする，そのとき配列の変化にもとづくエント ロピー変化 $\Delta S^{M}$ は

$$
\Delta S^{A r}=k \ln \frac{\left(N_{A}+N_{i}\right)}{N_{A} ! N_{i} !}
$$

スターリングの式 $\ln (N !)=N \ln N-N$ を用いて

$$
\begin{gathered}
\Delta S^{M}=k\left[\left(N_{A}+N_{i}\right) \ln \left(N_{A}+N_{i}\right)-N_{A} \ln N_{A}\right. \\
\left.-N_{i} \ln N_{i}\right]=-\left(N_{A}+N_{i}\right) k\left[\frac{N_{A}}{N_{A}+N_{i}} \ln \frac{N_{A}}{N_{A}+N_{i}}\right. \\
\left.+\frac{N_{i}}{N_{A}+N_{i}} \ln \frac{N_{i}}{N_{A}+N_{i}}\right] \quad \cdots \cdots \cdots \cdots(\mathrm{A}-14)
\end{gathered}
$$

1 モルの合金を考え $N_{A}+N_{i}=N_{0}\left(N_{0}:\right.$ アボガドロ数 $)$

としままたル分率 $n_{i}$ を用いれば

$$
\begin{aligned}
& N_{i} /\left(N_{A}+N_{i}\right)=n_{i} \\
& N_{A} /\left(N_{A}+N_{i}\right)=n_{A}=\left(1-n_{i}\right)
\end{aligned}
$$

なるゆえ

$$
\Delta S^{M}=-R\left[n_{i} \ln n_{i}+\left(1-n_{i}\right) \ln \left(1-n_{i}\right)\right]
$$

また， $A-A$ および $i-i$ 原子刘がてわれて $A-i$ 原子 対が生ずることによる絬合エネルギーの変化をつぎのよ うに $W$ と扔く.

$$
\phi_{A-i}-\frac{1}{2}\left(\phi_{A A}+\phi_{i-i}\right)=W
$$

無秩序配列では $A$ と $i$ が隣り合う確率は $N_{A} N_{i} /\left(N_{A}\right.$ $\left.+N_{i}\right)$ 飞比例するから

$$
\begin{gathered}
\Delta H^{\mathscr{W}}=\frac{N_{A} N_{i}}{N_{A}+N_{i}} W=n_{i}\left(1-n_{i}\right) N_{0} W \\
\equiv n_{i}\left(1-n_{i}\right) w
\end{gathered}
$$

$W$ または $w\left(=N_{0} W\right)$ を interchange energy という. 正則溶液とは哭秩序混合を仮定した溶液であるから

$$
\begin{aligned}
& \Delta F^{M}=\Delta H^{M}-T \Delta S^{M}=n_{i}\left(1-n_{i}\right) w \\
& \quad+R T\left[n_{i} \ln n_{i}+\left(1-n_{i}\right) \ln \left(1-n_{i}\right)\right] \cdots(\mathrm{A}-18)
\end{aligned}
$$

$w=$ 一定とすれば, $\Delta H^{M}$ は $n_{i}=0.5$ で最大となる。 こ のとき

$$
\Delta H^{M}=0.5 \times 0.5 w \text { または } w=4 \Delta H^{M} \quad \cdots(\mathrm{A}-19)
$$

また過鄱混合エネルギー $\Delta F^{e x}$ は一般につぎのように定 義される。

$$
\Delta F^{e x}=\Delta F^{M x}-\Delta S^{M} \text { random }
$$

むしあエントロピー項が（A-15) であらわされるとき は, (excess entropy=0ならば)

$$
\Delta F^{e x}=\Delta H^{M}
$$

また $F_{i}$ は

$$
\bar{F}_{i}=\frac{\partial \Delta F^{M L}}{\partial N_{i}}=\frac{\partial \Delta H^{H}}{\partial N_{i}}-T \frac{\partial \Delta S^{M I}}{\partial \bar{N}_{i}^{-}}
$$

(A-14)，(A-17) 式を $N_{i}$ で微分するこよにより

$$
\begin{aligned}
F_{i} & =\frac{N_{A}\left(N_{A}+N_{i}\right)-N_{A} N_{i}}{\left(N_{A}+N_{i}\right)^{2}} W \\
& -k T\left(\ln \left(N_{A}+N_{i}\right)-\ln N_{i}\right)
\end{aligned}
$$

$N_{A}, N_{i}$ をモ儿分率 $n_{i}$ に書き换え，さらに 1 モルにつ いての $F_{i}$ をとれば

$$
F_{i}=\left(1-n_{i}\right)^{2} w+R T \ln n_{i}
$$

ある濃度 $n_{i}{ }^{0}$ を $\bar{F}_{i}$ の標準状態にとるならば,

$$
\bar{F}_{i}{ }^{0}=\left(1-n_{i}{ }^{0}\right)^{2} w+R T \ln n_{i}{ }^{0}
$$

（16）式は（15）式にこの関係を代入してえられたあの である。

\section{会費請求および滞納の処理に関する事務処理要領}

(43. 1.12 第 20 回理事会)

1. 会費は，上（3月～8月）下（9月～2月）の二期分けてそれぞれ次斯分を12月拉よで 6 月 に一斎に請求する。

たメ゙し，途中入会の者については月割りによる残余の期間分を入会我垫亡同時に請求する.

2 . 余費請求後 3 力月以内に納入がない場合は会誌の発送を停止する。

3 ，会誌発送停止を通告の際，以後 3 力月以内に納入がない場合は除名する旨通告する.

4、一期分（6力月）滞納した場合は事情調査の上理事会に除名を申請する.

5，学生員, 官庁, 長期海外出張, その他特殊事情ある者については, 別途考虑する. 